\title{
Dispersion of the Yorùbá to the Ameri- cas: A Fatalist Hermeneutics of Orí in the Yorùbá Cosmos - Reading from Tutuoba: Salem's Black Shango Slave Queen
}

\author{
Emmanuel Adeniyi \\ Federal University, Oye-Ekiti, Nigeria \\ ayomercy2011@gmail.com
}

\begin{abstract}
Studies in African Diaspora often privilege the transatlantic slavery, Columbus' discovery of the New World, and African cultural codes in the Americas. To expand the scope of the studies, this article examines the metaphysical and ontological questions on the enslavement of the Yorùbá - an African ethno-nation whose members were condemned to slavery and servitude in the Americas during the inglorious transatlantic slave trade. I used metaphysical fatalism as a theoretical model to interrogate prognostications about dispersion of the Yorùbá from their matrix as expressed in their mythology. Being a predestining agent, I examined the role of ori (destiny) within the context of rigid fatalism and its textualisation in Prince Justice's Tutuoba: Salem's Black Shango Slave Queen. The article argues that the transatlantic enslavement of the Yorùbá is a fait accompli willed by their Supreme Deity. Though traumatic, transatlantic slavery reworlded Yorùbá cultural codes, birthed the Atlantic sub-group of the ethno-nation, and aided the emergence of Yorùbá-centric religions in the New World.
\end{abstract}

\section{Introduction}

The dispersion of the Yorùbá from their West African homeland to the Americas during the transatlantic slave trade has enjoyed appreciable attention in African Diaspora scholarship and Black cultural studies. Writers such as Pierre Verger, Lorand Matory, Toyin Falola, Edward Alpers, Kim Butler, Ann O'Hear, Faola Ifagboyede, Nelson Fashina, Olatunji Ojo, and many other 
critics have explored different nuances of the dispersion in their works. Most of the writers have also discussed various factors that aided the dispersion or enslavement of many able-bodied people belonging to the ethno-nation. ${ }^{1}$ They all validate the historical actuality of forced migration of the Yorùbá and a number of other Africans to the New World while the transatlantic slavery lasted. David Eltis, Russell Lohse, Rosalyn Howard, and Kevin Roberts, for instance, argue that most of the slaves carted off to the Americas - especially to Brazil, Cuba, Puerto Rico, Nicaragua, Suriname, Guyana, Barbados, St. Lucia, Jamaica, Costa Rica, the Bahamas, and many other countries in the Caribbean Basin - are of Yorùbá descent (see Alonso 34; Eltis 32; Lohse 130; Howard 169; Ojo 377; Roberts 180). This does not remove from the fact that other African ethnic groups such as the Bakongo, the Carabali, ${ }^{2}$ the Akan, the Ashanti, the Mandingo, the Fon, and the Ewe ${ }^{3}$ equally have considerable representations across the New World. Consequently, the capture, sale, forceful migration, and eventual enslavement of scores of Yorùbá slaves during the triangular trading in humans between 16th and 19th centuries throw up a philosophical argumentation on whether "the curse of Columbus" (Davidson 334; Yai 234) that afflicted the ethno-nation was predetermined, predestined or fortuitous. The argument is generated through a contextual interpretation linking the Yorùbá philosophical concept of orí (head or destiny) to the seemingly fatalist or hard-determinist character of the Yorùbá. Incidentally, the oral traditions of the ethno-nation bear proofs of fatalism and hard-determinism. In fact, the cultural practices of the people - with regard to their conception of orí as elédàa (creator) or what Babasehinde Ademuleya calls "the real essence of being" (214) and personality that "represents the individuality element in a person" (Balogun 118) - are also surfeited with metaphysical conceptions of fatalism and hard-determinism.

\section{Fatalism, Orí and Yorùbá Diasporic Character}

The dispersion of the Yorùbá is perhaps destined, considering their aetiological or cosmological myth, historical migration, and purported tortuous mythological journey from the Middle East to their present West African homeland (Alade 3). With regard to the Yorùbá myth of creation, it is implied

1 The rubric describes the Yorùbá globally as a people who are bound together and identified by the same culture, irrespective of spatial and temporal boundaries or linguistic contrariety that define them.

2 The name refers to the descendants of slaves from Efik or Calabar region in the present southern Nigeria.

3 See Hall Midlo Gwendolyn, Slavery and African Ethnicities in the Americas: Restoring the Links for elaborate information on the clustering of African ethnicities in the Americas. 
that the Supreme Deity of the ethno-nation (Olódùmarè) had an inkling of the dispersion, and had probably shown it through the metaphorical spreading of sand by a hen on a large expanse of water. In his seminal essay, "The Scattering of Oduduwa's Children", Faola Ifagboyede reveals that "the first act of God from the Yoruba cosmological view was an act of dispersion as the fivetoed chicken was instructed to scatter the earth - far and wide" (236). According to him, "The word 'scatter' implies a force that pushes parts irregularly in many directions" (Ifagboyede 236). Butler also believes that "The Yoruba are themselves a 'formalized' diaspora of Ile-Ife, which created sixteen kingships that maintained traditional links to their common homeland and each other" (216). Toyin Falola corroborates Butler's submission, positing that the notion of diaspora is not alien to the ethno-nation because its "oral narratives [even] privileged diasporic events and episodes" (8). He further maintains that the Yorùbá's "early mythologies are actually inaugurated by a diaspora: the story of the princes leaving Ile-Ife to establish kingdoms, settlements and towns is a story of a diaspora in formation" (8). According to him:

As the scattered princes of Ile-Ife were linked to an ancestor - Oduduwa - the unity in diversity was inscribed, reinforced by ceremonies and festivals. Thus, a notion of ancestral diaspora was created; also connected to a cultural diaspora as in, for example, the spread of the ideas of kingship and political centralization. Primary migrations fuelled secondary ones - if Oranmiyan is credited with founding Oyo-Ile, so too did many leave Oyo-Ile to create new settlements; and internal movements created a larger network, from Ile-Ife to Ife-Aana in Togo. (8-9)

Falola's view on the diasporic identity of the Yorùbá can be read as a blessing in disguise because founding new kingdoms apart from the existing ones helped the Yorùbá to spread out. This explains why Emmanuel Nelson, in his explication of the dispersal of Indians to different parts of the world, argues that the notion of diaspora brings about "aesthetics of reworlding" (181) as well as creation of new nations outside their original homeland. Consequently, rather than seeing diaspora as a loss, it can be conceived as a blessing in disguise. This is controversial in view of the fact that the enslaved and their descendants may not see anything beneficial in slavery, since it renders victims as strangers torn from their kith and kin, exiled from their communities, and left dishonoured and violated (See Hartman 5). However, there are two sides to every story. It is a given that the transatlantic slavery is obnoxious and debasing, but ignoring its other aspects may negate the spirit of holistic research needed to generate new knowledge. Although this position is contentious, my 
argument reifies Susane Colasanti's aphorism, “even in a bad situation, there's always a positive side. Even if you can't see it yet" (140).

To foreground the motif of dispersal in Yorùbá mythic account and the theophany of the gods in human affairs as revealed in Yorùbá aetiological myth, Ifagboyede writes that the act of dispersion first took place in Ilé-Ifẹ ${ }^{4}$ when "Olodumare, who is recognized by the Yoruba as being the Supreme Deity, manifested subordinate deities and commanded them to create and scatter the earth - far and wide" (226). ${ }^{5}$ Miguel Alonso also argues that "The history of the Yoruba people is one of dispersal" (33), which originated from the sacred city of Ilé-Ifẹ where Odúduwá became the "first human being to exist on the earthly realm of aye, the Yoruba dispersed outward to the corners of modern-day Yorubaland (stretching from southwestern Nigeria into the neighboring Republic of Benin) and through the horrors of the Atlantic slave trade to various points across the Western Hemisphere" (33). Their dispersal possibly reflects the intention of the creation god in Yorùbá cosmogony for the ethno-nation. He had presumably, one may argue, set out to spread or disperse the Yorùbá to different parts of the world. Though it can be claimed that after all the Yorùbá were not the only African ethnic group shipped to the New World, the overwhelming number of Yorùbá slaves in the Americas is indicative of factuality shaping the spreading out of members of the ethno-nation far beyond any other from the continent. ${ }^{6}$ This claim is corroborated by the Havana Court of Mixed Commission Registers between 1826 and 1839, and other relevant census figures between 1651 and 1867 indicating huge number of Yorùbá slaves in the Americas (see Eltis 23). Michele Reid lends credence to the massive dispersion of the Yorùbá to Cuba in particular, contending that between 1790 and 1880, records of slaves sold in Cuba indicate that of the almost seven thousand Africans of known origin, at least 9 per cent were Yorùbá (see Reid 115). She submits that many scholars also believe that the Yorùbá comprised the single largest proportion, at least 30 per cent, of the slaves imported to Cuba between 1817 and 1860 (see Reid 115).

The Yorùbá aetiological myth and the myth of their peregrination from the Middle East rather provide a prognosis of later happenings that would end up sending Odùduwà's scions to different parts of the world. Literally, the concept of diaspora or dispersion, from its Hellenic etymology (Diáspeírein),

4 It is a toponymy that literally means the place where the earth/world began to spread or expand. It is the cradle of the Yorùbá civilisation, and the birthplace of humanity in Yorùbá cosmology.

5 See Samuel Johnson's The History of the Yorubas and Adebanji Akintoye's A History of the Yoruba People for more information on the origins of the Yorùbá.

6 This position is contestable in view of the belief by some scholars that Yorùbá slaves were not the largest in the Americas during the transatlantic slave trade. 
entails spreading out or scattering (see Ages 3; Butler 189; Fox 367; Galván 114). In other words, the concept of diaspora is encapsulated in the act of spreading out or leaving a given location voluntarily or involuntarily to at least two or more different locations (see Butler 192). Metaphorically, it is interpreted that the Yorùbá Supreme Deity had intended or destined that his scions would scatter to the ends of the world, just like the Jewish God in Judeo-Christian mythology had done for the Jews. Their dispersion was predestined, and no mortal could prevent it from happening. Similarly, the Awole's (see Falola 9) ${ }^{7}$ imprecation on the Yorùbá and his throwing of arrows to the North, South, and West, with a malediction that his curse would carry them "to the sea and beyond the seas, [and that] slaves will rule" (Falola 9-10) over them is a prognostication of their forced migration, or better still a metaphorical rendition of their future enslavement. To Awole, the deserved punishment for his subjects who caused him pain and agony having betrayed him is for them to be sold into slavery and toil as slaves in faraway places. Awole's imprecation and the transatlantic slavery, therefore, lend itself to deterministic hermeneutics. Situating the enslavement of the Yorùbá within deterministic philosophy portrays Awole's execration as a just deserts or comeuppance for the ethno-nation. For the curse to take effect or for Olódùmarè's desire to be fulfilled, certain events must occur and interface. Such events can be surmised as: numerous internecine wars ${ }^{8}$ fought by the Yorùbá; the wiping out of some Yorùbá towns or sub-groups during the Yorùbá civil wars; the enslavement of many able-bodied sons and daughters of the ethno-nation coupled with their sale to European slave raiders and traders by local combatants; raiding of Yorùbá towns and villages by European slave merchants in connivance with some Yorùbá warlords and leaders; carting off of numerous able-bodied Yorùbá adults and children to the Americas; and their eventual transplantation to an environment completely alien to them. The point made here is that what confronted the Yorùbá from 16th to 19th centuries was beyond their control. Besides, their travails may have been preordained, predetermined, and predestined by their Supreme Deity. Those affected had no power over it, and could not alter what the gods had decided. This is fatalism at work!

7 Oba Awole, according to Toyin Falola, unleashed torrents of imprecations on the Yorùbá before killing himself following a "mutiny by a disloyal faction of the army who sent an empty covered calabash to the king, indicating Awole's rejection" (9).

8 Adeyemi Olusiji, for instance, identifies some internecine wars among the continental Yorùbá, including İjàyè-İbàdàn (1859-1861), Ẹ̀gbá-Rẹmọ war (1861-1865), İjẹ̣bú-Ẹ̀gbá trade war (1877), Kírijì war, that is, the war between the Ėkìtì and the İjẹsà against Îbàdàn people (1877-1886). Adeoti Oladele and Adeyeri Olusegun also identify Ẹ̀ fọnn-İbàdàn war (1850s), Ė fộn-İjệsà war (1862-1865). See: Adeyemi Olusiji’s “The Dramaturgy of Femi Osofisan"; Adeoti Oladele and Adeyeri Olusegun's "War and Peace in Eastern Yorubaland: Ẹ fọ̀n Alààyè and Her Neighbours (1815-1893)”. 


\section{Defining Fatalism and Hard-Determinism}

Fatalism is related to the philosophical conception which Abiodun Balogun calls hard-determinism. Hard-determinism expounds the fact that humans do not have any freedom or freewill. It "contradicts the view that human beings are free and supports that all human actions and events in the universe are caused" (Balogun 120). The Yorùbá slaves did not have a say in what befell them. As a matter of fact, those enslaved found themselves in a precarious situation they could not prevent. Besides, it was either a corollary of curses imposed on them or the desire of their Supreme Deity to ensure their reworlding and the reproduction of their culture outside their African matrix. The fate or the curse of Columbus that befell the Yorùbá can, therefore, be given a fatalist hermeneutics or contextualised within the precincts of metaphysical fatalism. Fatalism is a philosophical concept that emphasises the inevitability of certain events or happenings on which the gods have taken decision and the powerlessness of mortals to change or stop the events from happening. ${ }^{9}$ Fatalism is premised on John Hospers' phraseology: "whatever will be, will be" (322), or "What is going to happen will happen" (322). According to Balogun, the philosophical concept supports the belief that whatever happened or happens could not have been otherwise, since "certain events are such that they cannot but occur no matter what happens" (119). He posits further that fatalism does not allow for possible human efforts or self-criticism and self-involvement, since a fatalist views things with an undisturbed mind and has no sense of guilt or moral responsibility, because of the belief that everything is not within their control (119).

Fatalistic tendencies are evident in human actions and/or their belief systems which reinforce the inevitability of certain events from happenings, and the fact that no mortals can prevent the occurrence of what has been predestined. Adebola Ekanola also interprets this philosophical conception as "the viewpoint that whatever happens is unavoidable and could not have been otherwise" (43). The metaphysical fatalism that confronted the Yorùbá, similarly, bears intertextuality with the slavery of the Jews in Judeo-Christian historicity. The fatalist reading of the Jews' enslavement indicates a nexus in the misfortune that befell the Yorùbá slaves in the Americas and Jewish slaves in Babylonia and Egypt - what both ethno-national groups suffered is a fait accompli. As accounted for in the first canonical book of the Judeo-Christian Holy Writ, the Jews - who were taken into captivity - had no power to prevent it because their slavery was willed by their Supreme Deity:

9 See Stanford Encyclopaedia of Philosophy. 
Then He said to Abram: "Know certainly that your descendants will be strangers in a land that is not theirs, and will serve them, and they will afflict them four hundred years. And nation whom they serve I will judge; afterward they shall come out with great possessions [...] But in the fourth generation they shall return here". ${ }^{10}$

The Jewish God, just like the creation god in Yorùbá mythology, had predestined the Jews for 400 years of slavery. The decision was taken by their God; therefore, those who actually became slaves had no power to reverse or make Him rescind His decision. The creation god in Yorùbá mythology - as explained by Ifagboyede - had probably destined that the Yorùbá would one day become slaves in remote places and possibly wriggle through the multicultural flux or labyrinth of cultures in their host lands, overcome burdens of slavery, and eventually project a transcultural image. The transcultural image would later become the progeny of the marriage of Yorùbá cultural elements with Amerindian and European cultures, as well as Catholicism in the Americas. The Yorùbá experienced fatalism. The spin-off of the experience is their dispersion to the New World. This is where the Yorùbá philosophical view of ori as the source of life, the "ancestral guardian soul [...] the element [that] symbolizes human destiny and the whole of a person's personality" (Balogun 119) comes into play. To put it in a proper perspective, orí occupies the centre of sacredness and determines one's destiny, personality, and entire life course in Yorùbá cosmology (see Ademuleya 214; Ekanola 48). It is also the indicator of one's purpose in life, just as it has the secret of the Supreme Deity's plan for one's life (see Gbadegeshin 181). Orí is one of the three components of human person (see Balogun 118; Ekanola 46; Gbadegeshin 181; Oyelakin 88) which refers to the very essence of being, the personality, and soul (Ademuleya 214). The other two components include ara (human body) and èmí - the real life or breath of life (see Ekanola 46). Orí is the indicator of life's purpose or the bearer of one's destiny (see Balogun 118, 122; Oyelakin 84 ), or the "symbol of inner head or person" (Ademuleya 214). It is destiny that no one, except Ộn numilà, knows its content (see Oyelakin 85$)^{11}$ and it is "the personality-soul" (Dopamu 5) that is "capable of ruling, controlling and guiding the life and activities of man" (Awolalu 9). ${ }^{12}$ It is also "a potent vehicle through which man confronts life" (Balogun 42). ${ }^{13}$ According to Lekan Balogun, it occupies a central position in Yorùbá thought and worldview, because

\footnotetext{
10 Genesis 15:7

11 Ộnúnmilà is the Yorùbá deity of divination.

12 This is also cited in Dopamu (6).

13 See the Abstract
} 
it encapsulates the people's attempt at grasping selfhood and the very intricate and important ritual that surrounds it (42).

\section{Orí as Fatalist Agent in Prince Justice's Novel}

Prince Justice's Tutuoba: Salem's Black Shango Slave Queen is a novel with spatial and temporal settings in the pre and post-colonial Nigeria as well as slavery and post-slavery periods in the United States of America. As an eponymous novel, it narrates the life trajectory of a powerful reincarnated Yorùbá girl (Tutu Barbara Oba) who, during the transatlantic slave trade, is captured and carted off by slave raiders and merchants to plantations in Jamaica, Barbados, and later Boston in the United States of America. In her first or former life, Tutu is born a powerful witch-hunter in İjẹ bú-Òde in the 17th century. She embodies the Yorùbá thunder god (Șàngó) and his dreadful electric powers. In her reincarnated life, ${ }^{14}$ she is typified as a law graduate who secures a postgraduate admission to Franklin Pierce College in the US to study Intellectual Property Law. Despite all entreaties from her mother (Tinu) ${ }^{15}$ urging her not to go to the States, Tutu has to fulfil her destiny as a reincarnated girl born every seventh generation to help the poor and the oppressed. She is to contend with powerful spiritual forces in her reincarnated life in the US, the same way she contends with very powerful demonic powers that support slavery during her first life. Her life as a slave girl witnesses turbulence. Right from Africa, her first mother (Wura), who is a powerful witch too, tries hard to ensure that her only child is saved from the captivity of slave raiders, but she loses her life in the process.

Tutu eventually becomes the slave of Reverend Samuel Parris, a white cleric who is a missionary in İjẹ bú-Òde in 1682, having escaped being lynched in Kétu (Dahomey) due to the activities of slave raiders and traders. The locals want to avenge the incessant raids on their communities by white slave raiders on Reverend Parris, but he escapes to İjẹbú-Òde. He later becomes the teacher of Tutu and other children in the town. He escapes from the town through the help of Wura when the people of İjẹ bú-Òde decide to lynch him due to the recent raid on the town by white slave raiders and traders. Being a powerful miracle girl, Tutu becomes a channel for Șàngó's manifold powers. She fights and defeats all the white witches who are, at the same time, the wives of slave and plantation owners. Her life, however, ends abruptly when she gets drunk. One of the hindrances to the manifestation of Șàngó's power through her is that she must not take alcoholic drinks. She is pushed off a railing, falls and dies in Reverend Parris' house in Salem. This happens after

14 Her second life

15 Tutu's mother in her second or reincarnated life 
being tried and gaoled for being a witch in the historical Salem Witch Trial. In her reincarnated life, she returns to the US, and the person that facilitates her admission happens to be a descendant of Reverend Samuel Parris, Professor Samuel Parris. Professor Parris collects her from the airport after lightning has struck a white immigration officer who receives orders from spiritually powerful, highly connected people who are also descendants of those witches she kills in her first life to prevent her from entering the United States. Professor Parris takes her to his family house in Salem, the same house where Tutu lives as a slave and where she dies in her first life. She has a sense of déjà $v u$ on entering the house. However, her return to the US in her reincarnated life is to seek justice. Just as she defends African slaves during the transatlantic slavery, her present sojourn in America is to mete out retributive justice to the descendants of slave raiders and traders and plantation owners. Being spiritually powerful, they too are aware of this, hence their attempt to prevent her from entering the US.

The literary contextualisation of ori as a fatalist agent is indicated in the use of authorial intrusion as a narrative technique by Prince Justice in Tutuoba: Salem's Black Shango Slave Queen. The omniscient narrator in the text portrays the nexus between orí in Yorùbá cultural milieu, the dispersion of the ethno-nation to the New World, and their passivity or resolve not to take part in slave revolts in Jamaica, but accept their fate as an act of their Supreme Deity. Through the character of Tutu who metaphorises the collective voice of Yorùbá slaves in the Americas, the authorial intrusion representing the thoughts of Justice on fatalism is asserted:

One could attribute this passive trait of the Yoruba to the underlying religious and cultural belief that everything was predestined and couldn't be changed. Ori, meaning head, is the bearer of a person's destiny from heaven. This was the reason why most of the uprisings were orchestrated by Akans and Igbos, who shared nearly the same beliefs but less ardently. (160)

Justice pontificates about the importance of destiny in Yorùbá cosmology when Wura visits her daughter (Tutu) in a dream, telling her that all that happens to her is fated. Wura can be described as a psychopomp ${ }^{16}$ (see Adeniyi

16 Psychopomp in Jungian psychology refers to that personified wise man or woman, or animal in dreams who serves as a mediator between the conscious and the unconscious. The concept is "A psychic factor that mediates unconscious contents to consciousness, often personified in the image of a wise old man or woman, and sometimes as a helpful animal". See: Daryl Sharp's Jung Lexicon: A Primer of Terms \& Concepts. See Emmanuel Adeniyi's "Paratactic Narrative Mode and Taxonomic Conundrum of a Postmodern Verse Novel: Reading from Bernardine Evaristo”. 
161) who mediates between the conscious and the unconscious of Tutu, as she communicates with her daughter in dreams. She bridges the gap between the (sub)-liminal realm and the realm of awareness, revealing vital secrets to her daughter. Besides, it is her destiny not to fall in love, because whoever falls in love with her will pay dearly with his life. Tutu's questions to Wura: "Why mama? Why can't I have someone to love like everybody else? Why do I have to suffer?" (258) are greeted with the inevitability of one fulfilling one's destiny in life:

"We are all suffering my child. We are all tied to our destiny. It's whatever our head chooses before coming to Earth. You have to take whatever destiny serves you with your chin up. I have to leave, but before I do I want to warn you that two things can destroy one's destiny. They are alcohol and friends, be very careful of friends and do not drink the devil's water." (258)

Justice leverages on the fatalist train of thought to fictionalise the disruption that the transatlantic slavery caused to the Yorùbá. Told from the viewpoint of Tutu, it is revealed through Ifá divination that she will be a powerful witch-hunter, and that it is her destiny (ori) to combat powerful forces. It is also revealed that nothing can be done to prevent her from fulfilling her destiny. Since nobody knows what their orí has in stock for them, Tutu, in both her first and reincarnated lives, does not know that she is a special child born every seventh generation to serve as the tribune of the defenceless. In her first life, she is to defend slaves in the Americas; in her reincarnated life, she is destined to fight and prevail over the same powerful forces she contends with in her former or first life. In her former life as a slave girl, the forces prevail over her, but not after causing the death of almost all the people that aid and benefit from slavery and embody negative forces against her. In her reincarnated life, she is to continue where she stops as a slave girl and finish off her enemies or the enemies of her people. While explaining what Tutu's ori (destiny) has in stock for her in her first life, the Chief Priest - who takes delivery of her birth when Wura is having trouble delivering her - says Sàngó wants him to take the pregnant Wura to "an intersection, where three roads meet" (57). The phraseology, "intersection, where three roads meet", is metaphoric and suggests wayfaring. It foreshadows the journey that the baby will later undertake in life and the tortuous course of the journey. It equally foregrounds the tropes of diaspora, migration or peregrination. According to an old witch, who attends Tutu's naming ceremony and gives a premonitory vaticination, the girl: 
is an exceptional Dada child, who has come to wreak havoc upon us. She wants to take on us, the keepers of the underworld and I wish her no blessings, for the soil of the underworld shall burn her feet and the sun shall burn her scalp. No, I shall not remain silent, but rebuke the one that wishes to wage war on the womb. She that wishes to rule the underworld shall be nothing more than a slave! (60)

Since it is willed by Olódùmarè that Tutu will undertake a journey and her destiny as a witch-hunter will manifest while away from her place of birth, this actually comes to pass as the girl is captured one early morning when her mother is away attending a witch meeting in their coven. All attempts to save her fail, as Wura loses her life in the process. This is an indication that no one can succeed in altering the decision of the gods, or what has been predestined and sealed by one's orí. Wura, upon returning to her husband's compound, finds out about the capture of her only child, and goes after the raiders believing that she can use her supernatural powers to secure the release of Tutu. However, this proves abortive as higher powers that are hell-bent on making the girl fulfil her destiny thwart Wura's efforts:

Wura reached into her blouse and brought out a tiny gourd, which supposedly had magical powers and started incanting, "As the moon puts the sun to sleep and a rocking mother's breasts puts her baby to sleep [...] I command you to sleep! As it appeared to be taking effect and four of the guards yawned and sat down to rest, some birds with high shrills alerted them. She tried once again, but with the birds fluttering their wings above them and continuing their high-pitched noise, the men rose again. Wura sighed with frustration on realizing its futility. "Why are you working against me, you spirits of the realm? Please don't betray me," she whispered desolately as she looked up to the heavens. A voice answered her. "She has to go. It's her destiny. Don't try to stop it or you will only stop your own life!" (85, emphasis mine)

The above excerpt is an indication of rigid fatalism. The gods have decided beforehand on the fate or destiny of Tutu; no mortals can make them rescind their decision. Contrary to Balogun's belief that human destiny can be altered either for good or bad through supernatural means, ${ }^{17}$ it is posited here that

17 It needs be stressed that the postcolonial Yorùbá society toes this line of thought. Many Yorùbá people, possibly due to the influence of Christianity and Islam as well as Western education, believe that one's destiny can be made right through prayers. Christians among them premise their faith in the Bible verses: "If the foundations be destroyed, what can the righteous do? (Psalm 11:3); the righteous can go back to God, because "the 
certain issues that the gods or supernatural forces or one's orí have resolved beforehand may be unalterable. Benedict Ibitokun corroborates this belief among the Yorùbá, stressing that prayer or sacrifice is of no effect as far as the matter of changing the course of destiny is concerned. He submits that the Yorùbá hold tenaciously to the belief that no god can change human destiny. In fact, the foregoing belief underpins the Yorùbá axiom, àyànmó ò gbóògùn, orí lele éjọ́ (destiny has no cure; it is the head that judges). In other words, no one can escape their destiny, because the orí of everyone has predestined what will happen to every human person in life. In a Yorùbá folktale, narrated in Funké Michaels'Against all Odds: a Tale of 7 Amazons, affirming the importance of destiny (àyànmó) and orí in human life, the primal influence of orí in determining what becomes of one's destiny is asseverated:

Alo o! ... (Alo!)

Ojo kan wa... (Owa bi ewa!)

Oro mi dori o dori

O dori ori, a ran mo l'ajo si'mo lo

O dori ayanmo, a t'orun yan fun eeyan

Ibi ori dani si l'aagbe

Ibi ori ran de, l'aare

Ori eni l'onise eni

Ayanmo eda o gbo ogun!

A tale! A tale!

There came a day [. . .] like beauty itself [. . .]

My word stands upon 'orí' the personal deity

The one who sends a child on a journey

And travels along with the child

My word stands upon 'Àyànmó' the personal Destiny

The one who makes one's choices

Even before one's birth

Where orí has appointed

There one dwells

Where orí has decided

There one goes

One's orí must take the lead

As there is no cure for one's destiny!" (44)

effectual fervent prayer of a righteous man avails much" (James 5:16). Moslems also believe that powerful duas exist in the Quran that can be used to make supplication to Allah on anything, including changing a bad destiny. 
However, in his soft-deterministic interpretation of orí, Balogun believes that the Yorùbá sometimes use the channels of sacrifices (ebo) or consulting to know "the kind of ori one had chosen and to perhaps alter an unfavourable destiny through the help of some spiritual forces, and by the application of the right type of sacrifices [because] ebo among the Yoruba is believed to be capable of influencing human destiny either for good or bad" (126-127). The foregoing submission lends itself to interrogation because it can be argued that it is the destiny of mankind to go through the process of birth and death. Death is inevitable, and mortality is the lot of every living being. Everyone that is born is fated to experience death. This is the order of nature; besides, various religious testaments asseverate this. It can be conveniently submitted that no amount of spiritual appeasement can alter this natural order. Though it looks like rigid fatalism, it is sanctioned by the Providence. However, 'Segun Adekoya believes that both determinism and freewill are mere philosophical speculations, while their postulations may not be valid with regard to the Yorùbá belief on predestination. According to him:

The Yorùbá believe that a person who chose a good orí still needs to pray, make sacrifice, and work hard to fulfil the destiny, because evil forces abound that could change the destiny. The Yorùbá believe that with sacrifice it is possible to delay the day of death. Hence, Ò'rúnmilà bears the praise name Ap'ijọ ikúdà (one who changes the day of death). The reason why Ộnumilà could achieve the feat is because he is Elẹriiìpin (Witness of destiny). He was present when the choice of orí was made. In Ifá, death is not perceived as all evil but as a divine favour. It is an opportunity for renewal (reincarnation). ${ }^{18}$

Adekoya is of the opinion that determinism may not aptly describe the Yorùbá view on life and death, considering their belief in appeasement of the gods to change any misfortune or ill-luck that attends one's fate. He maintains that the Yorùbá folktale which expresses lack of cure for one's destiny, once chosen, is problematic and should be interrogated, since many Yorùbá still consult Ifá priests to seek solutions to their spiritual problems. He claims that the statement may portray Ifá priests as being redundant or deprive them of their source of livelihood. It should be noted, however, that not all appeasements to the gods receive favourable response. While some requests are granted by the gods with the acceptance of sacrifice offered to them, they do reject some as well and withhold their àse (force of approval) to some

18 Professor 'Segun Adekoya is of the Department of English, Obafemi Awolowo University (OAU), Ilé-Ifẹ.. He made this comment in his review of this article in April 2018. 
supplications. Despite the supposed renewal or regenerative function of death, as submitted by Adekoya, humanity abhors death. I build on the foregoing argument and submit that no person can wish away death. It may be delayed, but cannot be averted. The consequence of this is that death in Yorùbá cosmology is deterministic or fatalistic. When a person chooses a wrong ori, offering sacrifices or prayers to the gods may not alter the course of their destiny because the gods reserve the rights to either answer the prayers or not. The fate of Oedipus in Sophocles' Athenian tragedy, Oedipus Rex, and Odewale in Ola Rotimi's The Gods Are Not to Blame further validates the futility of altering the course of one's destiny. Sophocles/Odewale is fated to kill his biological father and marry his mother. All efforts to prevent this fail; yet, the gods are not to blame for the choice made by Sophocles' or Ola Rotimi's protagonist when choosing his orí.

The story of Tutu and the ethno-nation she metaphorises is fatalistic. In order to fulfil her destiny, Tutu eventually finds herself on a slave ship to Jamaica. She emerges as a leader of other African slaves and everyone looks up to her for help, medication, and spiritual assistance. To foreground the fatalist condition of her life, an old slave woman, whom Tutu thinks could be her grandmother sold into slavery long time ago, has predicted long before Tutu's capture and enslavement that a young Yorùbá slave girl is coming to the island to save her people. A conversation with Kojo - one of the leaders of African slaves in Jamaica - reveals the longing of the enslaved for her, as the slaves are expectant, following the prophecy given by the old slave woman that someone is coming to liberate them:

The previous Mama Orisha had told us there would be some woman from the orishas to help us, who had real powers that would guide us out of here. She was an herbalist, but did not possess any spiritual power. We started calling her Mama Orisha since we needed one right away. She died the night before you arrived at a very old age in the next plantation. When you arrived the following day, we were shocked to see the resemblance and when we heard of what happened on the ship to those who wanted to rape you, we knew you were the real Mama Orisha. (163)

After the slave uprisings in Jamaica, Tutu goes with her master Reverend Samuel Parris and her erstwhile captor, Anthony Smith, to Barbados, and later to North America where she begins to wage battle against demonic forces embodied by wives of plantation owners and slave merchants in Boston, Salem, and other places in Southern part of the United States. In one of their numerous meetings to annihilate Tutu, eleven witches meet in Annapolis to stop 
the vessel carrying Tutu, Anthony Smith, Reverend Samuel Parris, and his sister (Judith) as well as some slaves, from coming to their area. Mrs Angela Rogers is the wife of the largest tobacco grower in Annapolis and the convener of the meeting:

I called you here today as a matter of emergency. I might have told some of you of an alien force that threatens to disrupt our lives and prosperity, although we were not sure of its arrival or the form it would take. It is a spiritual threat from Africa that would cause a lot of problems, if allowed to land on this coast. Luckily, we were able to identify its movement towards our coast yesterday. Otherwise, it would have entered unnoticed and we would have probably been too late. It is not certain whether it is male or female, but since we were lucky to identify its presence on the ship, we have to sink the ship and all its cargo. That is the reason why I summoned everyone tonight. We need the full strength of the coven to command all the spirits and elements. So let's start. You all know what to do. (191)

Șàngó strikes the coven with thunderbolts and many of the witches get injured. Series of attacks are waged against Tutu by combined supernatural forces in Salem, but the gods avenge her. She comes out of Salem Witch Trial victorious, while those who are using demonic powers to manipulate church children in Salem are all hanged. She dies, having neglected the warning given to her to desist from alcohol, hence her reincarnation to complete her assignment of meting out retributive justice to descendants of those who have a hand in the transatlantic slavery. Considering her life trajectory, Tutu metaphorises fate or fatalism. She is a symbol of dispersion and the resolve of the Yorùbá Supreme Deity to scatter his children far and beyond their immediate matrix. The futility of saving Tutu by her mother, the prognostication of being sold into slavery, and her future mandate of hunting down witches read much like a metaphor of misfortune that befell the Yorùbá during the 400-year-old transatlantic slavery. Like Tutu, their enslavement was a fait accompli, and there was nothing anybody could do to prevent it. The collective destiny of the Yorùbá at the period of slavery may probably have been explored by Olódùmarè as an avenue to achieve his desire for his people - to spread or scatter them beyond Ilé-Ifẹ. This interpretation appears valid in view of the fact that the Yorùbá oral tradition holds that sixteen direct children of Odùduwà left Ilé-Ifẹ to found their own kingdoms (see Falola 8), thus enabling them to spread out beyond their West African homeland. 


\section{Conclusion}

To possibly interrogate the fatalist argument surrounding the travails of the Yorùbá during the transatlantic slavery, philosophical questions may be generated as to whether their enslavement could have been prevented or not, or whether certain actions should have been taken to prevent it. Their enslavement appears to be divine with the objective of possibly achieving their already foretold dispersion and the transplantation of their culture in another environment different from their original homeland. However painful the means or process of the transplantation may be, the reworlding or the reproduction of Yorùbá culture in the Americas is a blessing in disguise. This is exactly what Tutu, in Justice's Tutuoba: Salem's Black Shango Slave Queen, indexes. Her enslavement brings sorrow to her family, but she fulfils her destiny of reaching the New World, and punishing evil deeds, as well as the diabolical roots of slavery, imperialism, and colonialism. While fulfilling her destiny, she is able to plant her culture and acculturate other slaves with different cultural backgrounds. Like her, the Yorùbá slaves and their descendants in the Americas toiled to plant and deepen the Yorùbá cultural practices in the New World. They also globalise the culture, especially its religious sub-culture. The emergence of Yorùbá-centred religions in the Americas, such as Candomblé, Santeria, Macumba, Umbanda, Batuque, Trinidadian Șàngó, Voodoo, and many others attest to the positivity of reworlding the Yorùbá and their cultural codes in the Americas. Albeit through the painful and ignoble channel of slavery, these gains would have been impossible if the ethno-nation had not dispersed. With this message, Prince Justice succeeds in conveying to the reader an alternative view of transatlantic slavery different from its dominant conception as a mere trading in humans with preponderant conquest narratives. Through the novel, the reader is made to see the other side of the historical event, even though it came at a huge cost to the enslaved and their progenies.

\section{Works Cited}

Ademuleya, Babasehinde A. "The Concept of Ori in the Traditional Yoruba Visual Representation of Human." Nordic Journal of African Studies 16. 2 (2007): 212-220.

Adeniyi, Emmanuel. "Paratactic Narrative Mode and Taxonomic Conundrum of a Postmodern Verse Novel: Reading from Bernardine Evaristo's Lara." Critique: Studies in Contemporary Fiction 61.2 (2020): 157-170.

Adeoti, Ezekiel Oladele and James Olusegun Adeyeri. "War and Peace in Eastern Yorubaland: È fọ̀n-Alaàyè and Her Neighbours (1815-1893).” Global Journal of Political Science and Administration 2.1 (2013): 1-7. 
Adeyemi, Adesola Olusiji. “The Dramaturgy of Femi Osofisan.” PhD diss., University of Leeds, 1999.

Ages, Arnold. The Diaspora Dimension. Dordrecht: Springer, 1973.

Akintoye, S. Adebanji. A History of the Yoruba People. Dakar, Senegal: Amalion Publishing, 2010.

Alade, Adebisi D. "Stories of Migration and State Formation in Yorubaland: A Re-Assessment of Yoruba Myth and Legend of Creation." Rosetta 17 (2015): $1-23$.

Alonso, Miguel C. The Development of Yoruba Candomble Communities in Salvador, Bahia, 1835-1986. New York: Palgrave Macmillan

Alpers, Edward A. "Defining the African Diaspora." Paper presented to the Centre for Comparative Social Analysis Workshop, 25 October 2001, https://www.google.com.ng/?gws_rd=ssl\#q=Edward+alpers\%27+defining+African+diaspora. Accessed 3 August 2015.

Awolalu, Omosade O. Yoruba Beliefs and Sacrifice Rites. London: Longman, 1979.

Balogun, Lekan. "Ori: Ritual and Yoruba Drama of Existence." IOSR Journal of Humanities and Social Science 17.1 (2013): 42-47.

Balogun, O. Abiodun. "The Concepts of Ori and Human Destiny in Traditional Yoruba Thought: Soft-Deterministic Interpretation.” Nordic Journal of African Studies 16.1 (2007): 116-130.

Butler, Kim. "Defining Diaspora, Refining a Discourse." Diaspora 10.2 (2001): 189-219.

Colasanti, Susane. Take Me There. New York: Penguin, 2008.

Davidson, Basil. The Search for Africa: History, Culture, Politics. New York and Toronto: Random House, 1994.

Dopamu, Adelumo P. "Continuity and Change: The Yoruba Belief in Life after Death." A Paper Prepared for "Continuity and Change: Perspectives on Science and Religion" on March 7, 2006, in Philadelphia, a Program of Metanexus. http://www.metanexus.net/conferences/pdf/conference2006/ Dopamu.pdf. (accessed 11 January 2017).

Ekanola, Adebola Babatunde. "A Naturalistic Interpretation of the Yoruba Concepts of Ori." Phisophia Africana 9.1 (2006): 41-52.

Eltis, David. "The Diaspora of Yoruba Speakers, 1650-1865: Dimensions and Implications." In The Yoruba Diaspora in the Atlantic World, eds. Toyin Falola and Matt D. Childs, 17-39. Bloomington and Indianapolis: Indiana UP, 2004.

Falola, Toyin. "Atlantic Yoruba and the Expanding Frontiers of Yoruba Culture and Politics." A Paper Presented at J. F. Odunjo Lecture, University of Ibadan, www.obafemio.com. Accessed 29 October 2012. 
Fashina, Nelson O. "Post-Colonial Reading Strategies and the Problem of Cultural Meaning in African/Black Literary Discourse." Journal of Pan African Studies 2.5 (2008): 60-77.

Fox, Robert Elliot. "Diasporacentrism and Black Aural Texts." In The African Diaspora: African Origins and New World Identities, eds. Isidore Okpewho, Carole Boyce Davies, and Ali A. Mazrui, 367-378. Bloomington and Indianapolis: Indiana University Press, 1999.

Funké, Michaels. Against all Odds: A Tale of 7 Amazons. Bloomington: AuthorHouse, 2011.

Galván, Fernando. "Metaphors of Diaspora: English Literature at the Turn of Centuries."English Language Overseas Perspectives and Enquiries 5.1-2 (2008): 113-123.

Gbadegeshin, Olusegun. "Destiny, Personality and the Ultimate Reality of Human Existence: A Yoruba Perspective." Ultimate Reality and Meaning 7.3 (1984): 173-188.

Gwendolyn, Midlo Hall. Slavery and African Ethnicities in the Americas: Restoring the Links.Chapel Hill: The University of North Carolina Press, 2005.

Hartman, Saidiya. Lose Your Mother: A Journey along the Atlantic Slave Route. New York: Farrar, Straus and Giroux, 2007.

Hospers, John. An Introduction to Philosophical Analysis. London: Routledge and Kegan Paul, 1981.

Howard, Rosalyn. "Yoruba in the British Caribbean: A Comparative Perspective on Trinidad and the Bahamas."." In The Yoruba Diaspora in the Atlantic World, eds. Toyin Falola and Matt D. Childs, 157-176. Bloomington and Indianapolis: Indiana UP, 2004.

Ibitokun, Benedict M. African Drama and the Yoruba World-view. Ibadan: Ibadan University Press, 1995.

Ifagboyede, Faola. "The Scattering of Oduduwa's Children." In Orisa: Yoruba Gods and Spiritual Identity in Africa and the Diaspora, eds. Toyin Falola and Ann Genova, 225-241.Trenton, NJ and Asmara, Eritrea: Africa World Press, 2005.

Johnson, Samuel. The History of the Yorubas. Lagos: C.S.S, 1973.

Justice, Prince. Tutuoba: Salem's Black Shango Slave Queen. London: AU Media Book, 2007.

Lohse, Russell. "Africans in a Colony of Creoles: The Yoruba in Colonial Costa Rica." In The Yoruba Diaspora in the Atlantic World, eds. Toyin Falola and Matt D. Childs, 130-156. Bloomington and Indianapolis: Indiana UP, 2004.

Matory, J. Lorand. "The English Professors of Brazil: On the Diasporic Roots of the Yoruba Nation." Comparative Study of Society and History 41.1 (1999): 72-103. 
Nelson, Emmanuel S. Reworlding: The Literature of the Indian Diaspora. New York: Greenwood, 1992.

O'Hear, Ann. "The Enslavement of Yoruba." In The Yoruba Diaspora in the Atlantic World, eds. Toyin Falola and Matt D. Childs, 56-73. Bloomington and Indianapolis: Indiana UP, 2004.

Ojo, Olatunji. "The Slave Ship Manuelita and the Story of a Yoruba Community, 1833-1834.” Revista Tempo 23.2 (2017): 361-382.

Oyelakin, Richard T. "Questionable but Unquestioned Beliefs: A Call for a Critical Examination of Yoruba Culture." Thought and Practice: A Journal of the Philosophical Association of Kenya (PAK) 5.2 (2009): 81-101.

Reid, Michele. "The Yoruba in Cuba: Origins, Identities, and Transformations." In The Yoruba

Diaspora in the Atlantic World, eds. Toyin Falola and Matt D. Childs, 112-129. Bloomington and Indianapolis: Indiana UP, 2004.

Roberts, Kevin. "The Influential Yoruba Past in Haiti." In The Yoruba Diaspora in the Atlantic World, eds. Toyin Falola and Matt D. Childs, 177-182. Bloomington and Indianapolis: Indiana UP, 2004.

Sharp, Daryl. Jung Lexicon: A Primer of Terms \& Concepts.www.innercitybooks.net/pdf/books/junglexicon.pdf, accessed 20 November 2017.

Verger, Pierre F. “The Status of Yoruba Religion in Brazil." Kiabara: Journal of Humanities 1 (1978): 29-79.

Yai, O. Babalola. "Yoruba Religion and Globalization: Some Reflections." In Orisa Devotion as World Religion: The Globalization of Yoruba Religious Culture, eds. Jacob Kehinde Olupona and Terry Ray, 233-246. Madison, Wisconsin: University of Wisconsin Press. 